\title{
Investigating the Possibility of Using Recycled Industrial Wastewater Instead of Potable Water in Concrete Mixture
}

\section{Amir Hossein Askariyeh*}

Department of Civil and Environmental Engineering, Iran Azad University, Branch of Yazd, Iran

*Corresponding author: Amir Hossein Askariyeh, Department of Civil and Environmental Engineering, Iran Azad University, Branch of Yazd, Iran, Tel: +989131575685; E-mail: aaskariyeh@yahoo.com

Received date: September 28, 2018; Accepted date: December 29, 2018; Published date: January 07, 2019

Copyright: (c) 2019 Askariyeh AH. This is an open access article distributed under the terms of the Creative Commons Attribution License, which permits unrestricted use, distribution and reproduction in any medium, provided the original author and source are credited.

\section{Introduction}

Iran is located in the Middle East with a population of approximately 81 million people (2017). The Middle East in general and Iran in particular are located in an arid region of the world. Iran has a chronic shortage of water. It is estimated there is some form of drought in 97 percent of the country. In an 8 -month period (September 23, 2017-May 21, 2018) the country has received 151.5 millimeters of rain while the long-term averages are 214.6 millimeters which indicates a 29-perecnt drop in mean precipitation nationwide. The driving factors behind water shortages are numerous. Some are natural and others man-made. One of the biggest factors is population growth. The population of Iran doubled between 1976 and 2001, going from 33 million to 66 million Iranians. The population is still rising, and currently stands at over 80 million people. And as this figure rises, the volume of renewable water resources available per capita drops. It is already critically low. $35 \%$ of the populations are living in areas experiencing water shortages and droughts. Global warming is contributing to bodies of water drying out, and the problem is expected to worsen as climate change increases. The socio-economic changes happening alongside this exacerbate the problem.

Fresh water is a precious commodity here. Population and economic growth has increased the demand for fresh water in the region. Limited supply and increased demand has created a challenge for governments and construction industry. Therefore this article is investigating the possibility of using alternative sources of water with the aim of reducing the demand for the limited supply of fresh water.

Ibrahim al Ghusain and his Colleague used car wash wastewater on investigate effect of reusing wastewater in concrete mixture in different situation as Temperature and long term and varying degrees of treatment on compressive strength and they found that territory treated car wash wastewater has more compressive strength than others [1]. In another case Shahiron Shahidana and his colleagues worked on effect of reusing car wash wastewater in different quantity for measuring, tensile strength and Modulus of Elasticity (MOE) and compressive strength of concrete. In this paper was shown the optimum percentage of car wash wastewater as fresh water replacement in concrete mixes is $20 \%$ [2].

For the purpose of the article recycled industrial wastewater from an industrial park in the city of Yazd of Iran was used in mixing concrete and its effect on compressive strength of concrete was analyzed.

Concrete samples for testing purposes were mixed using ordinary Portland cement and common aggregate used in concrete work for general construction purposes. Samples were prepared according to ASTM standard of C 192 and after curing in the laboratory environment for different periods they were crushed to determine the compressive strength.

In this experiment test results indicated that all samples prepared with treated industrial wastewater exhibit an increased compressive strength compared to the samples prepared with potable water. This finding shows promising results for conservation of fresh water supplies by using alternative sources of water for concrete mix.

Keywords Recycled industrial wastewater; Potable water; Concrete mixture; Chronic shortage

\section{Materials}

\section{Cement}

The cement used in this study was ordinary Portland cement type CEM 2, that purchased from Yazd cement Company. This cement is widely used in the construction industry in Iran and the quantity of cement for the experiment was $350 \mathrm{~kg} / \mathrm{m}^{3}$. It's compiled with requirements ASTM C150.

The physical and chemical properties of cement shown in Tables 1 and 2 respectively.

\begin{tabular}{|c|c|}
\hline Property & OPC \\
\hline Specific gravity & 3.15 \\
\hline Passing grain size & $78 \%$ \\
\hline Median grain size & $18 \mu \mathrm{m}$ \\
\hline Blaine specific surface & $300 \mathrm{~m} 2 / \mathrm{kg}$ \\
\hline Initial setting time & $145 \mathrm{Min}$ \\
\hline Final setting time & $270 \mathrm{Min}$ \\
\hline
\end{tabular}

Table1: Analyze of chemical properties of cement.

\begin{tabular}{|c|c|}
\hline Component & $\%$ \\
\hline Silicon dioxide, $\mathrm{SiO}_{2}$ & 21.2 \\
\hline Aluminium oxide, $\mathrm{Al}_{2} \mathrm{O}_{3}$ & 5.5 \\
\hline Iron oxide, $\mathrm{Fe}_{2} \mathrm{O}_{3}$ & 3.1 \\
\hline Calcium oxide, $\mathrm{CaO}$ & 63.7 \\
\hline Magnesium oxide, $\mathrm{MgO}$ & 1.5 \\
\hline Sodium oxide, $\mathrm{Na}_{2} \mathrm{O}$ & 0.18 \\
\hline
\end{tabular}




\begin{tabular}{|c|c|}
\hline Potassium oxide, $\mathrm{K}_{2} \mathrm{O}$ & 0.71 \\
\hline Sulfur trioxide, $\mathrm{SO}_{3}$ & 2.63 \\
\hline Loss on ignition & 0.96 \\
\hline
\end{tabular}

Table 2: Analyze of chemical properties of cement.

\section{Aggregates}

The aggregate for this experiment consisted of 30 percent gravel with maximum size of $20 \mathrm{~mm}$ and 70 percent sand and fines with maximum size of $9 \mathrm{~mm}$. The source of this aggregate was Shehneh village which supplies the majority of aggregate for concrete in Yazd province. Water over cement ratio $(\mathrm{w} / \mathrm{c})$ for this experiment was 0.38 . Coarse aggregates according to the ASTM C33 requirements [7]. ASTM C33 and BS 882 standards were used to control the aggregates sizes using a sieve analysis $[8,9]$.

\section{Mixing water}

Wastewater samples were obtained from wastewater treatment plant. Table 1 shows the chemical analyses of the wastewater sample.

Wastewater samples were obtained from refinery of Yazd province industrial state Co. First the experimental has done with fresh water as basis of the research and second used treated wastewater for investigation compressive strength. The experimental has wastewater treatment plant. Table 1 shows the chemical analyses of the wastewater sample.

The chemical properties of industrial wastewater were analyzed according to USEPA standard method and compared with the standard specifications [3-5].

\section{Mix proportion of concrete}

\section{Mix design and sample preparation}

All concrete specimens were designed to have a target mean strength of $25 \mathrm{MPa}$ according to the Department of Environment (DOE) method [6-10].

The properties of mixing for this study are demonstrated in Table 3 for concrete manufacturing.

The ingredients for concrete mixture were weighed in separate container. The materials were mixed in a rotating pan in accordance with ASTM C 136. The overall mixing time was about 4 minutes. The mixtures were compacted. The slumps of concrete have experimented according to ASTM C 143. The sample of wastewater maintained in temperature room for one day, after that used for concrete manufacturing.

A total of sixteen sample was prepared, four with potable water, four with fresh treated wastewater and four samples exposed to sun and four samples with treated wastewater stored in shade for investigation the effect of sun on chemical property of wastewater and finally on compressive strength of concrete.

\begin{tabular}{|c|c|c|c|}
\hline Water & Gravel & Sand and fines & Cement \\
\hline 2.315 & 9.77 & 22.699 & 5.609 \\
\hline
\end{tabular}

Table 3: The analysis of materials for concrete mixtures.

To determine the compressive strength for each category four cubes $(150 \mathrm{~mm} \times 150 \mathrm{~mm} \times 150 \mathrm{~mm})$ were used. Two samples were cured for 7 days, one sample was cured for 28 days and one sample was cured for 90 days for investigation the effect of long time on chemical property of wastewater and compressive strength.

\section{Concrete testing procedure}

The manufacturing and curing process of concrete were according to ASTM C171 standards. The concrete slump tests were performed according to ASTM C143 [11]. The compressive strength of concrete was evaluated in accordance with ASTM C496 [12].

\section{Results and Discussion}

\section{Water quality analysis}

The chemical analysis performed on treated wastewater and presents in Table 4. The data indicated all the ingredients in the treated wastewater were with Standard range but only one parameter is higher than normal mood and that's silica. After research determined the type of wastewater contain some silica, about $20 \mathrm{mg} /$ liter and the parameter helps to increase compressive strength concrete also if there is not silica in wastewater, won't be problem.

The reason for presence of the silica is the wastewater is output of a manufacture site Tile and Ceramic manufacture and was determined the type of wastewater and it helped to increase compressive strength concrete than normal mood (The normal mood of compressive strength concrete is about $25 \mathrm{MPa}$ ).

The range of $\mathrm{PH}$ value is in the range of typical industrial wastewater according to the Standard A-1978 which varies from 6.0 to 9.0. The quantity of useful and harmful integrate is, in normal range and $\mathrm{PH}$ is between 4.5-8.5. The result of the experiment demonstrates suitable condition for reusing wastewater in concrete mixture. Furthermore, BS EN 1008, (2002) mentioned that the typical pH value of water for mixing concrete should be at least higher than four $(>4)$. Therefore, industrial wastewater can potentially be used in concrete mixes due to its reasonable characteristics for mild environmental conditions the Solid suspended particles is less than $2000 \mathrm{ppm}$ and Total soluble material (TDS) is less than $2000 \mathrm{ppm}$ and Chloride should be less than $1000 \mathrm{ppm}$.

\begin{tabular}{|c|c|c|c|}
\hline Row & Factor & Unit & Quantity \\
\hline 1 & Electrical conductivity (EC) & $\mu \mathrm{s} / \mathrm{cm}$ & 3354 \\
\hline 2 & (Turbidity) & FTU & 2 \\
\hline
\end{tabular}


Citation: Askariyeh AH (2019) Investigating the Possibility of Using Recycled Industrial Wastewater Instead of Potable Water in Concrete Mixture . Int J Waste Resour 9: 362. doi:10.35248/2252-5211.19.9.362

Page 3 of 5

\begin{tabular}{|c|c|c|c|}
\hline 3 & Chloride & Mg/Lit & 905.4 \\
\hline 4 & Nitrate (NO3) & Mg/Lit & 0.44 \\
\hline 5 & Nitrite (NO2) & $\mathrm{Mg} / \mathrm{Lit}$ & $<1$ \\
\hline 6 & $(\mathrm{Hg})$ & $\mu g / l$ & $<1$ \\
\hline 7 & $\mathrm{As}$ & $\mathrm{Mg} / \mathrm{l}$ & $<0.1$ \\
\hline 8 & $\mathrm{~Pb}$ & $\mathrm{Mg} / \mathrm{Lit}$ & $<0.05$ \\
\hline 9 & $\mathrm{Cd}$ & $\mathrm{Mg} / \mathrm{Lit}$ & $<0.1$ \\
\hline 10 & $\mathrm{Cr}$ & $\mathrm{Mg} / \mathrm{Lit}$ & $<0.1$ \\
\hline 11 & $\mathrm{Cu}$ & $\mathrm{Mg} / \mathrm{Lit}$ & $<0.1$ \\
\hline 13 & $\mathrm{Zn}$ & $\mathrm{Mg} / \mathrm{Lit}$ & $21 \mathrm{mg} / \mathrm{liter}$ \\
\hline 14 & Silica & & $<$ \\
\hline
\end{tabular}

Table 4a: Analysis Ingredients in Wastewater.

\begin{tabular}{|c|c|c|c|}
\hline Beam & Factor & Unit & Quantity \\
\hline 1 & $\mathrm{PI}$ & - & 6.5 \\
\hline 2 & Temperatures & $\mathrm{CO}$ & 12 \\
\hline 3 & Electrical conductivity (EC) & $\mu \mathrm{s} / \mathrm{cm}$ & 850 \\
\hline 4 & (Turbidity) & FTU & 35 \\
\hline 5 & Oxygen Required Biochemistry & $\mathrm{Mg} / \mathrm{Lit}$ & 155 \\
\hline 6 & Oxygen Required Biochemistry & $\mathrm{Mg} / \mathrm{Lit}$ & 70 \\
\hline 7 & soluble Salts (TDS) & $\mathrm{Mg} / \mathrm{Lit}$ & 570 \\
\hline 8 & Nitrate (NO3) & $\mathrm{Mg} / \mathrm{Lit}$ & 5.3 \\
\hline 9 & Nitrite (NO2) & $\mathrm{Mg} / \mathrm{Lit}$ & 1.5 \\
\hline 10 & (P) & $\mathrm{Mg} / \mathrm{Lit}$ & 16.5 \\
\hline 11 & (Oil) & $\mathrm{Mg} / \mathrm{Lit}$ & 8.7 \\
\hline 12 & Total Calorim & (Number in $100 \mathrm{cc}$ ) & $<1100$ \\
\hline
\end{tabular}

Table 4b: Analysis Ingredients in Wastewater.

\begin{tabular}{|c|c|c|c|c|c|c|}
\hline Row & Sampling date & Date of receipt of the sample & Test date & Factor-unit & Result & Type of procedure \\
\hline 1 & $2016 / 17 / 7$ & $2016 / 17 / 7$ & $2016 / 18 / 7$ & TSS(ppm) & 11 & Gravimetric \\
\hline 2 & $2016 / 17 / 7$ & $2016 / 17 / 7$ & $2016 / 18 / 7$ & $\mathrm{Cl}(\mathrm{ppm})$ & 511.2 & Titrimetric \\
\hline 3 & $2016 / 17 / 7$ & $2016 / 17 / 7$ & $2016 / 18 / 7$ & $\mathrm{Fc}(\mathrm{ppm})$ & 0.1712 & Direct Air Acetylene Flame Atomic Absorption spectrometric \\
\hline 4 & $2016 / 17 / 7$ & $2016 / 17 / 7$ & $2016 / 18 / 7$ & $\mathrm{Cu}(\mathrm{ppm})$ & $<0.1$ & Direct Air Acetylene Flame Atomic Absorption spectrometric \\
\hline 5 & $2016 / 17 / 7$ & $2016 / 17 / 7$ & $2016 / 18 / 7$ & $\mathrm{Zn}(\mathrm{ppm})$ & 0.1171 & Direct Air Acetylene Flame Atomic Absorption spectrometric \\
\hline
\end{tabular}

Table 4c: Analysis Ingredients in Wastewater. 
Citation: Askariyeh AH (2019) Investigating the Possibility of Using Recycled Industrial Wastewater Instead of Potable Water in Concrete Mixture . Int J Waste Resour 9: 362. doi:10.35248/2252-5211.19.9.362

Page 4 of 5

\section{Properties of Fresh Concrete}

\section{Slump test}

In this study, the concrete slump test was conducted according to ASTM C143.

\section{Mechanical Properties of Concrete}

\section{Compressive strength}

Tables 5-9 Shown the comparison compressive strength with industrial wastewater in sun and shade with potable water.
In order to investigate the long term two samples cured for 90 days. The wastewater for one sample was exposed to sun for 7 days.

The standard strength for sample prepared with fresh wastewater was $31.1 \mathrm{~kg} / \mathrm{cm}^{2}$.

The strength properties for other samples are indicated in Tables 6-9.

The maximum strength value belonged to 90 days sample prepared with wastewater kept in shade.

\begin{tabular}{|c|c|c|c|}
\hline Concrete Type & Strength on 7 Days (MPa) & Strength on 28 Days (MPa) & $\begin{array}{c}\text { ASTM C1602 Minimum Wastewater Concrete At 7 Days (>90\%) of control } \\
\text { strength }\end{array}$ \\
\hline CS-PW 1 & 24.3 & 31.1 & $124 \%$ \\
\hline CS-PW 2 & 31.9 & 34.5 & $138 \%$ \\
\hline
\end{tabular}

Table 5: Analysis of 7 and 28-days compressive strength of concrete mixture with potable water.

\begin{tabular}{|c|c|c|c|}
\hline Concrete Type & $\begin{array}{c}\text { Strength on 7 Days } \\
\text { (MPa) }\end{array}$ & $\begin{array}{c}\text { Strength on 28 Days } \\
\text { (MPa) }\end{array}$ & \begin{tabular}{c} 
ASTM C1602 Minimum Wastewater Concrete At 7 Days (>90\%) of control strength \\
\hline CS-IWW 1
\end{tabular} \\
\hline CS-IWW 2 & 28.4 & 34.1 & $136 \%$ \\
\hline \multicolumn{2}{|l}{ (CS-PWW 1: Concrete Sample- Industrial Waste Water- Sample 1) } \\
\hline
\end{tabular}

Table 6: Analysis of 7 and 28-days compressive strength of concrete mixture with industrial wastewater.

\begin{tabular}{|c|c|c|c|}
\hline Concrete Type & Strength on 7 Days (MPa) & Strength on 28 Days (MPa) & $\begin{array}{c}\text { ASTM C1602 Minimum Wastewater Concrete At 7 Days (>90\%) of control } \\
\text { strength }\end{array}$ \\
\hline CS-IWW-Shade 1 & 29.4 & 36 & $144 \%$ \\
\hline CS-IWW-Shade 2 & 29.5 & --- & -- \\
\hline (CS-PWW-S 1: Concrete Sample- Industrial Waste Water- Shade- Sample 1) & \\
\hline
\end{tabular}

Table 7: Analysis of 7 and 28-days compressive strength of concrete mixture with industrial wastewater was remained 7 Days in Shade.

\begin{tabular}{|c|c|c|c|}
\hline Concrete Type & $\begin{array}{c}\text { Strength on 7 Days } \\
\text { (MPa) }\end{array}$ & $\begin{array}{c}\text { Strength on 28 Days } \\
\text { (MPa) }\end{array}$ & ASTM C1602 Minimum Wastewater Concrete At 7 Days (>90\%) of control strength \\
\hline $134 \%$ & 27.3 & 33.6 & $134 \%$ \\
\hline CS-IWW-Sun 2 & 26.5 & --- & -- \\
\hline \multicolumn{4}{|l}{ (CS-PWW-Sun 1: Concrete Sample- Industrial Waste Water- Shade- Sample 1) } \\
\hline
\end{tabular}

Table 8: Analysis of 7 and 28-days compressive strength of concrete mixture with industrial wastewater was remained 7 Days in Sun.

\begin{tabular}{|c|c|c|}
\hline Concrete Type & $\begin{array}{c}\text { Strength on 90 Days } \\
\text { (MPa) }\end{array}$ & $\begin{array}{c}\text { ASTM C1602 Minimum } \\
\text { Wastewater Concrete At 7 } \\
\text { Days (>90\%) of control } \\
\text { strength }\end{array}$ \\
\hline CS-IWW-Shade & 41.1 & $164 \%$ \\
\hline
\end{tabular}

\begin{tabular}{|c|c|c|}
\hline CS-IWW-Sun & 36.4 & $145 \%$ \\
\hline (CS-PWW-Sun 1: Concrete Sample- Industrial Waste Water- Shade- Sample) \\
\hline
\end{tabular}

Table 9: Analysis of 90-days compressive strength of concrete mixture with industrial wastewater was remained 7 Days in Sun and Shade. 
Citation: Askariyeh AH (2019) Investigating the Possibility of Using Recycled Industrial Wastewater Instead of Potable Water in Concrete Mixture . Int J Waste Resour 9: 362. doi:10.4172/2252-5211.1000362

Page 5 of 5

5-9 Shown the compressive strength of manufactured concrete between industrial wastewater with potable water. According to Table 9, the compressive strength of industrial wastewater is about $50 \%$ higher than normal mood while the minimum limit of compressive strength is about $90 \%$ specified in ASTM C1602. In some cases as CSIWW-Shade the Compressive strength is about double of normal range and a sample of potable water is the least compressive strength than others.

\section{Conclusion}

The following conclusions are warranted regarding the effect of using treated industrial wastewater instead of potable water on compressive strength concrete:

The experiment determined using treated wastewater is possible for concrete mixture and it helps to save water supplies and increase the compressive strength of concrete.

The chemical contents as silica of the type of treated industrial wastewater is generally higher than potable water but as long as chemicals are within the ASTM standard limits, there is no negative effect on strength of concrete even it helps to has higher compressive concrete.

When treated industrial wastewater remained under the sun for 7 days there was a reduction in compressive strength of concrete when compared with samples prepared with the same water remained in shade. However, strength properties of concrete in both cases (with wastewater remained in sun and shade) were higher than those prepared with potable water.

The study was about effect of industrial wastewater on compressive strength of concrete but the study should be extended to investigate the effect of the wastewater on durability and tensile strength of concrete and reducing consumption cement for concrete manufactured.

\section{References}

1. Al-Ghusain I, Terro M (2003) Use of treated wastewater for concrete mixing in Kuwait. Kuwait journal of science and Engineering 30: 213-228.

2. Shahidan S, Senin MS, Kadir ABA, Yee LH, Ali N (2017) Properties of Concrete Mixes with Carwash Wastewater. In MATEC Web of Conferences 87: 10-18.

3. US EPA (1994) EPA's Polluted brochure. United States Environmental Protection Agency, United States.

4. Neville AM (1995) Properties of Concrete, 4th ed. London: Pearson.

5. Martin C (2013) Influence of Supplementary Cementitious Materials (SCMs) on concrete durability. Ecoefficient concrete 153-197.

6. ASTM C150 (2018) Standard Specification for Portland Cement.

7. ASTM C33 (2003) Specification for Concrete aggregates, Pennsylvania, United States: American Society for Testing and Materials.

8. BS 882 (1992) Specification for Aggregates from Natural Sources for Concrete, London: British Standards Institution.

9. ASTM C143 (2005) Test Method for Slump of Hydraulic Cement Concrete, Pennsylvania, United States: American Society for Testing and Materials.

10. DOE (1988) Design of Normal Concrete Mixes. Building Research Establishment, Watford, United Kingdom: Department of the Environmental.

11. BS EN 1008 (2002) Mixing Water for Concrete Specification for Sampling, Testing and Assessing the Suitability of Water, Including Water Recovered from Processes in the Concrete Industry, as Mixing Water in Concrete, London: British Standards Institution.

12. BS EN 1008 (2002) Mixing Water for Concrete Specification for Sampling, Testing and Assessing the Suitability of Water, Including Water Recovered from Processes in the Concrete Industry, as Mixing Water in Concrete, London: British Standards Institution. 